\title{
The Effect of Biodiesel Derived from Waste Oil on Engine Performance and Emission Characteristics
}

\author{
İbrahim Aslan Reşitoğlu ${ }^{1} \&$ Ali Keskin ${ }^{2}$ \\ ${ }^{1}$ Department of Automotive Technology, Technical Sciences Vocational School, Mersin University, Mersin, \\ Turkey \\ ${ }^{2}$ Department of Automotive Engineering, Engineering and Architecture Faculty, Cukurova University, Adana, \\ Turkey \\ Correspondence: İbrahim Aslan Reşitoğlu, Department of Automotive Technology, Technical Sciences \\ Vocational School, Mersin University, Mersin 33343, Turkey. Tel: 90-324-361-0001.
}

Received: July 2, 2018

Accepted: July 25, 2018

Online Published: July 31, 2018

doi:10.20849/jess.v1i1.432

URL: https://doi.org/10.20849/jess.v1i1.432

\begin{abstract}
To produce biodiesel from waste oil and use it as an alternative fuel in compression ignition (CI) engines is an efficient way to eliminate this harmful compound. In this experimental study, the effects of biodiesel derived from waste oil on emission and performance characteristics of CI engine were investigated. The production of biodiesel was realized at the condition: $9 \mathrm{wt} \%$ acid catalyst amount, $9: 1$ molar ratio, $60^{\circ} \mathrm{C}$ reaction temperature and $120 \mathrm{~min}$ reaction time. Biodiesel and diesel were mixed with different volumetric ratios and the properties of each blend were analyzed. Each blend was tested with a direct injection CI engine to see the effect of biodiesel on performance and emission characteristics. In conclusion, blends showed similar results in terms of performance comparing to diesel. The use of biodiesel derived from waste oil led to decrease in hydrocarbon (HC), carbon monoxide (CO) emissions and smoke opacity up to $81.25 \%, 55.02 \%$ and $40.48 \%$ respectively while led to slight increase in nitrogen oxides $\left(\mathrm{NO}_{\mathrm{x}}\right)$ emissions in general.
\end{abstract}

Keywords: biodiesel, diesel engine, exhaust emissions, waste oil

\section{Introduction}

Fossil-based fuels used in the production of energy release a large share of pollutant emissions into the environment. The pollutant emissions, especially $\mathrm{CO}, \mathrm{HC}, \mathrm{NO}_{\mathrm{x}}$ and $\mathrm{PM}$, cause regional air pollution that threaten people health and environment worldwide (Sanjid et al., 2014). They have also contributed to the enhancement of the natural greenhouse effect led to climate change. Because of their high proportion in releasing pollutant emissions, fossil-based fuels are considered as the main reason of global climate change (Resitoglu et al., 2015).

Use of alternative sources instead of fossil-based fuels has been a common application by researchers to prevent the damage of fossil-based fuels. In researches carried on alternative sources, the use of local, renewable and clean sources, the increase of productivity and ensuring diversity of sources are the main factors that have been considered. The alternative sources met these factors may be listed as solar, wind, hydro, nuclear and biomass energy. Among these alternative energy sources, biomass energy has so many advantages to be alternative for fossil-based fuels. Biodiesel as one of the biomass-based fuels is an alternative and renewable source for fossil-based diesel (Qi et al., 2016; Ahmed et al., 2014).

The high production cost of biodiesel depend on raw material is the main obstacle in biodiesel's widespread use by comparison with diesel. In order to decrease the cost of biodiesel, waste oils that are easily available have become resources for biodiesel production (Qi et al., 2016). The use of waste oils instead of high cost vegetable oil in production of biodiesel is an effective way to reduce raw material costs (Eguchi et al., 2015). It is estimated that the use of waste oils instead of vegetable oils can reduce biodiesel production costs by $60-90 \%$ (Kochepka et al., 2015). In addition, using waste oils may also help to solve the problem of waste oil disposal.

Low cost feedstocks such as used cooking oils and animal fats are important sources for biodiesel production (Chuah et al., 2016). Many investigations have been carried out using biodiesel produced from waste oils in diesel engines. In these investigations, including waste cooking oils first, many waste oils from different origins 
such as frying, fish, chicken, palm, coffee, limed fleshing, plastics, etc. have been used (Eguchi et al., 2015; Gürü et al., 2010; Chuah et al., 2016). Unlike these feedstocks, waste oil originated from kitchens, restaurants or refectories is an alternative feedstock in biodiesel production.

This experimental study aimed to demonstrate that this feedstock could be used as an alternative fuel in diesel engines. In this purpose, biodiesel production from waste oil was realized with esterification method. Blends of biodiesel and diesel were prepared in different volumetric ratios and fuelled CI engine to see the effects on diesel engine characteristics.

\section{Material and Methods}

Waste oil contained higher levels of free fatty acids was obtained from Çukurova University refectory's sewerage system. The waste oil was mixture of oil, water, solids and fats. It was obtained from this system is averagely $200 \mathrm{~L}$ per week. Six different samples of waste oil used in biodiesel production were obtained at different times. All samples were mixed and specifications of composition were identified. The density, viscosity and free fatty acid values of composition were obtained as $909 \mathrm{~kg} / \mathrm{m}^{3}, 28.7 \mathrm{~mm}^{2} / \mathrm{s}$ and $65.15 \%$ respectively. Because of these high rates, esterification method was used for biodiesel production.

Biodiesel production from waste oil was carried out optimally with $9 \mathrm{wt} \%$ acid catalyst amount and mol. ratio of $9: 1$, at reaction temperature of $60^{\circ} \mathrm{C}$ and reaction time of $120 \mathrm{~min}$. Methanol and sulphuric acid were used as alcohol and catalyst respectively. The flow diagram of the biodiesel production from waste oil is given in Figure 1. As shown in figure, after filtering, washing and drying processes, waste oil was subjected to esterification reaction with sulphuric acid and methanol. After the esterification reaction, water and catalyst were separated and crude biodiesel was washed and dried, in order to obtainment of pure biodiesel.

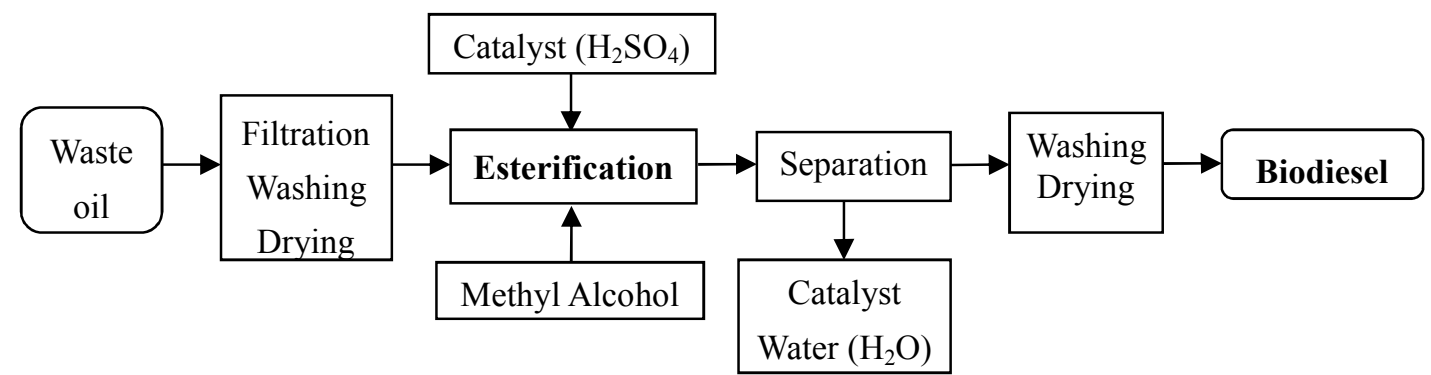

Figure 1. Flow diagram of biodiesel production from waste oil

Biodiesel produced from waste oil was mixed with diesel by volumetric rate of $10 \%, 20 \%, 30 \%$ and $40 \%$. Each blend was named according to biodiesel rates (B10, B20, B30 and B40). Chemical and physical properties of blends were analyzed at Fuel Analysis Laboratory of Cukurova University. The equipments used for analyzing specifications of test fuels are given in our previous study (Keskin et al., 2015).

The physical and chemical properties of biodiesel and its blends with diesel are presented in Table 1. Biodiesel, diesel and diesel-biodiesel blends specifications have been determined according to EN 14214 Standards. The viscosity of pure biodiesel was found higher than that of diesel and standards. The lower heating value (LHV) decreased with use of biodiesel. Compared to diesel, biodiesel has a lower LHV at a rate of $12.97 \%$. The LHV of blends decreased depending on increase rate of biodiesel content in the blend. The reduction rates in LHV of $\mathrm{B} 10, \mathrm{~B} 20, \mathrm{~B} 30$ and B40 were obtained as $1.56 \%, 3.23 \%, 4.99 \%$ and $6.70 \%$ respectively. The flash point of biodiesel is higher than that of diesel. The high flash point of biodiesel makes its storage and transportation easy and possible (Shadid \& Jamal, 2008). 
Table 1. Physical and chemical properties of test fuels

\begin{tabular}{lccccccccc}
\hline Quality & Unit & $\mathrm{B} 10$ & $\mathrm{~B} 20$ & $\mathrm{~B} 30$ & $\mathrm{~B} 40$ & Biodiesel & Diesel & EN14214 & EN590 \\
\hline Density & $\mathrm{kg} / \mathrm{m}^{3}$ & 836 & 843 & 850 & 856 & 896 & 829 & $\mathbf{8 6 0 - 9 0 0}$ & $\mathbf{8 2 0 - 8 6 0}$ \\
Viscosity $\left(40^{\circ} \mathrm{C}\right)$ & $\mathrm{mm}^{2} / \mathrm{s}$ & 2.4 & 3.2 & 3.91 & 4.78 & 9.88 & 2 & $\mathbf{3 . 5 - 5 . 0}$ & $\mathbf{2 . 0 - 4 . 5}$ \\
Acid value & $\mathrm{mgKOH} / \mathrm{g}$ & 0.27 & 0.48 & 1.07 & 1.58 & 3.92 & 0.05 & Max. 0.5 & - \\
Flash point & ${ }^{\circ} \mathrm{C}$ & 63.5 & 64.5 & 65.4 & 66.5 & 96.8 & 62.5 & Min. 101 & Min 55 \\
Sulfur content & $\mathrm{wt} \%$ & 0.0813 & 0.0770 & 0.0706 & 0.0672 & 0.0538 & 0.0826 & $\mathbf{0 . 0 0 1}$ & Max 0.2 \\
Copper strip corrosion & - & $1 \mathrm{a}$ & $1 \mathrm{a}$ & $1 \mathrm{a}$ & $1 \mathrm{a}$ & $1 \mathrm{a}$ & $1 \mathrm{a}$ & & $\mathbf{1}$ \\
Lower heating value & $\mathrm{kJ} / \mathrm{kg}$ & 44016 & 43271 & 42485 & 41719 & 38913 & 44717 & & - \\
\hline
\end{tabular}

Table 2. Technical specifications of test engine

\begin{tabular}{|c|c|}
\hline Model of engine & Antor Diesel 4 LD 640 \\
\hline Number of cylinder & 1 \\
\hline Displacement & $638 \mathrm{~cm}^{3}$ \\
\hline Bore $\mathrm{x}$ Stroke & $95 \mathrm{~mm} \times 90 \mathrm{~mm}$ \\
\hline Compression ratio & $17: 1$ \\
\hline Max. speed & $3000 \mathrm{~min}^{-1}$ \\
\hline Max. power & $10 \mathrm{~kW}$ \\
\hline Max. torque & $43 \mathrm{Nm}\left(1800 \mathrm{~min}^{-1}\right)$ \\
\hline Injection system & Direct injection \\
\hline Method of cooling & Air-cooled \\
\hline
\end{tabular}

An air-cooled direct-injection single-cylinder Lombardini 4LD $640 \mathrm{CI}$ engine was used at the performance and emission tests. Table 2 indicates the specifications of test engine. The smoke opacity values (K) of biodiesel, diesel and diesel-biodiesel blends were analyzed with CAP 3200 gas analyzer and Testo 350-S gas analyzer was used to measure $\mathrm{HC}, \mathrm{NO}_{\mathrm{x}}$ and $\mathrm{CO}$ emissions. Details of these equipments are shown in Table 3. Schematic view of experimental set-up is given in Figure 2. The test engine was mounted on a platform and probes of gas analyzers were connected to the exhaust outlet line. A hydraulic dynamometer was used to install load to engine. The experimental uncertainties are given in Table 4.

Table 3. The main properties and resolution of the gas analyzers

\begin{tabular}{lccc}
\hline Equipment & & Range of measurement & Stability \\
\hline \multirow{3}{*}{ Testo 350-S } & $\mathrm{NO}_{\mathrm{x}}$ & $0-3000 \mathrm{ppm}$ & 1 \\
& $\mathrm{HC}$ & $0-20000 \mathrm{ppm}$ & 1 \\
CAPELEC CAP3200 & $\mathrm{CO}$ & $0-10000 \mathrm{ppm}$ & 1 \\
\hline
\end{tabular}




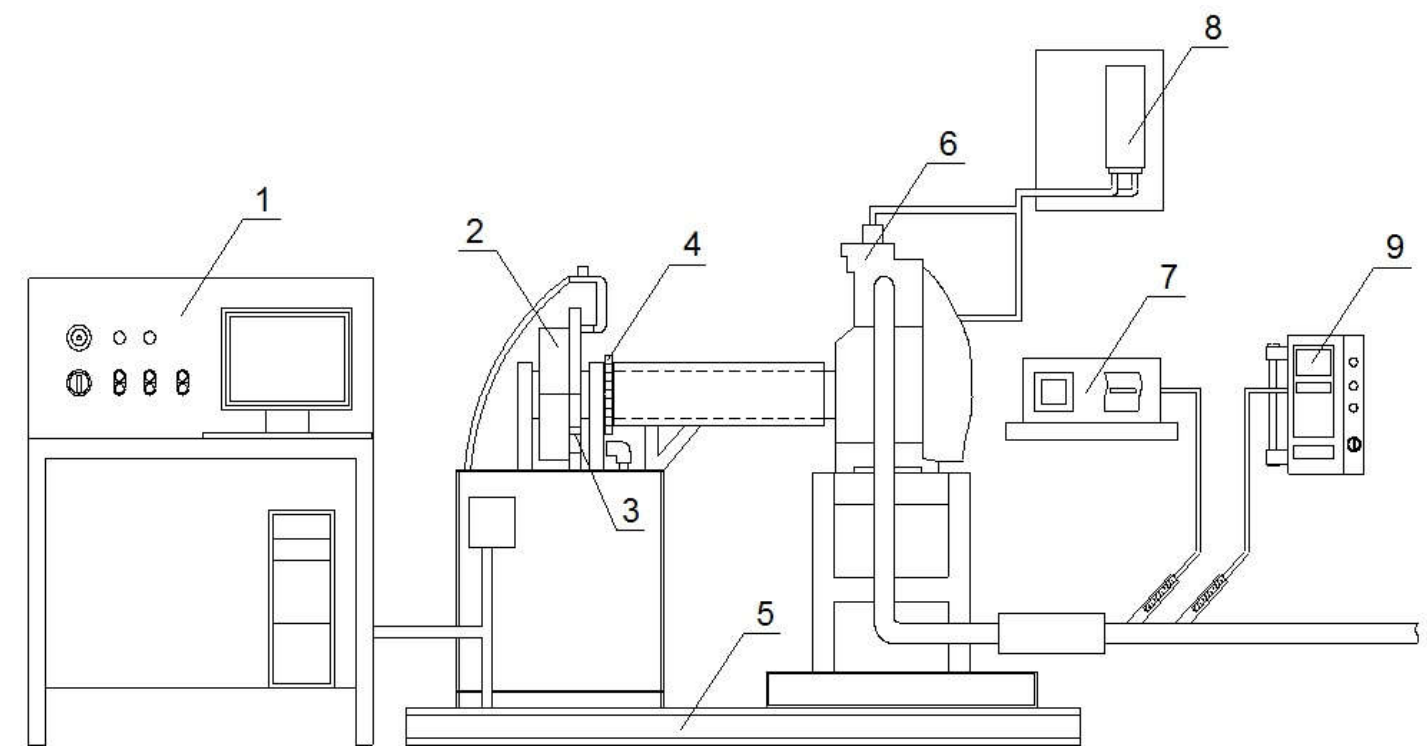

Figure 2. Schematic figure of test rig (1. Control board, 2. Hydraulic-dynamometre, 3. Loading unit, 4.Rev-meter, 5. Platform, 6. Diesel engine, 7. Smoke meter, 8. Fuel tank, 9. Diesel emission analyzer)

Table 4. Uncertainties in measurements

\begin{tabular}{lcc}
\hline Measurements & & Uncertainty $\mathbf{\pm \%}$ \\
\hline Power & $\mathrm{kW}$ & 0.32 \\
Torque & $\mathrm{Nm}$ & 0.29 \\
BSFC & $\mathrm{g} / \mathrm{kWh}$ & 0.97 \\
Engine speed & $\mathrm{min}^{-1}$ & 0.13 \\
Smoke & $\mathrm{m}^{-1}$ & 2.27 \\
CO & $\mathrm{ppm}$ & 2.36 \\
$\mathbf{H C}$ & $\mathrm{ppm}$ & 1.93 \\
$\mathbf{N O}_{\mathbf{x}}$ & $\mathrm{ppm}$ & 2.76 \\
\hline
\end{tabular}

The engine was run for $20 \mathrm{~min}$ before the tests to reach active temperature of engine. To determine the emission and performance characteristics of test fuels, engine was removed to the maximum speed that it could be reached and the hydraulic dynamometer was started to load. Tests were carried out from 1200 to 2600rpm engine speeds at full load conditions. Each test was implemented for three times and the average of readings was counted. The engine power, torque and break specific fuel consumption (BSFC) were measured at the engine performance tests while $\mathrm{CO}, \mathrm{NO}_{\mathrm{x}}, \mathrm{HC}$ and smoke opacity were determined at the engine emissions tests.

\section{Results and Discussion}

\subsection{Engine Performance}

Figure 3 and Figure 4 show engine torque and power curves respectively at full load condition and different engine speeds. As shown in the figures, despite the slight decrease in engine power and torque, it can be said that the engine power and torque characteristics of blends are similar to pure diesel. At all engine speeds, the engine power and torque decreased depending on the increase rate of biodiesel content in the blend. The maximum decrease in power and torque was obtained as $4.66 \%$ with B40 at 2600rpm compared to diesel. Averagely the decreases in power and torque were measured as $0.77 \%, 1.56 \%, 2.50 \%$ and $3.24 \%$ for B10, B20, B30 and B40 respectively. The lower LHV of biodiesel is the main reason for the decrease in engine power and torque. Besides, higher density and viscosity of biodiesel may cause flow problems that lead to lower combustion and thermal efficiency which decrease performance characteristics of diesel engine. Other investigators (Özsezen et al., 2009; Keskin et al., 2008) reported similar results. 


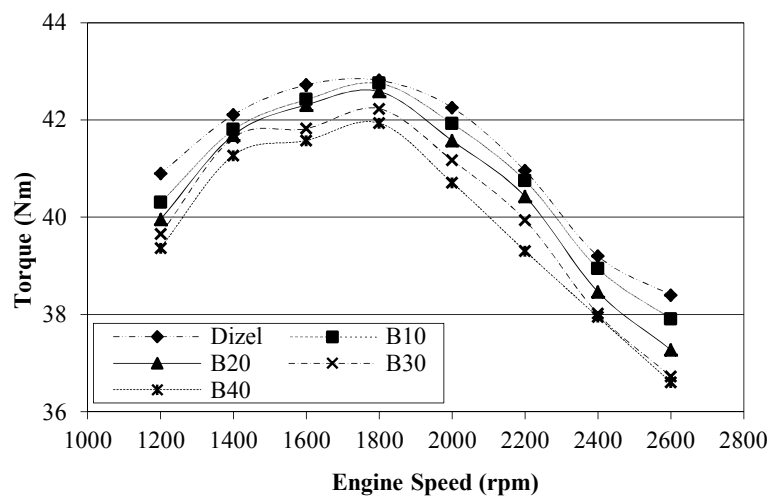

Figure 3. Torque at full load condition

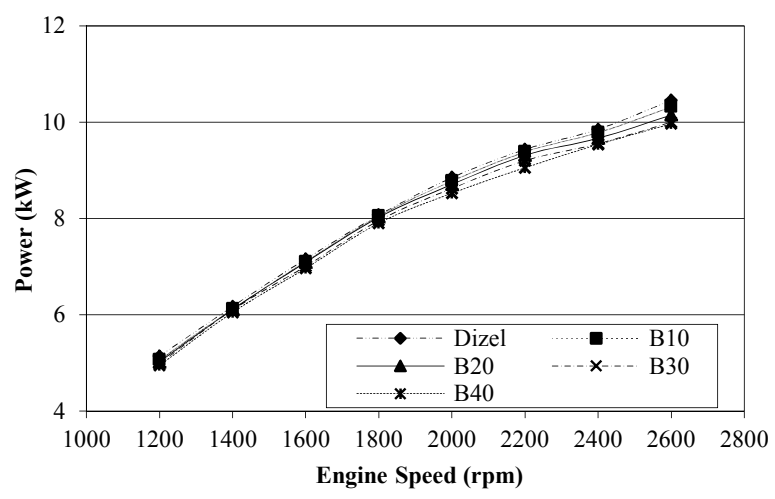

Figure 4. Power at full load condition

The BSFC values of blends were higher than that of diesel in general (Figure 5). Compared to diesel, higher viscosity, lower LHV and higher density of blends led to increase in BSFC. The BSFC was reached the lowest value at 2400rpm with biodiesel, diesel and diesel-biodiesel blends while the highest BSFC values were measured at 1200rpm. Compared to diesel, the maximum increase in BSFC was obtained as $4.86 \%$ with B40 in $1800 \mathrm{rpm}$. Considering all the engine speeds, B10, B20, B30 and B40 led to decrease in BSFC as a rate of $0.93 \%$, $1.96 \%, 2.61 \%$ and $3.65 \%$ respectively. The BSFC reduction rates of blends were obtained parallel with the reductions rates in power and torque. Similar results were obtained in studies of other researches (Gürü et al., 2010; Kalligeros et al., 2003).

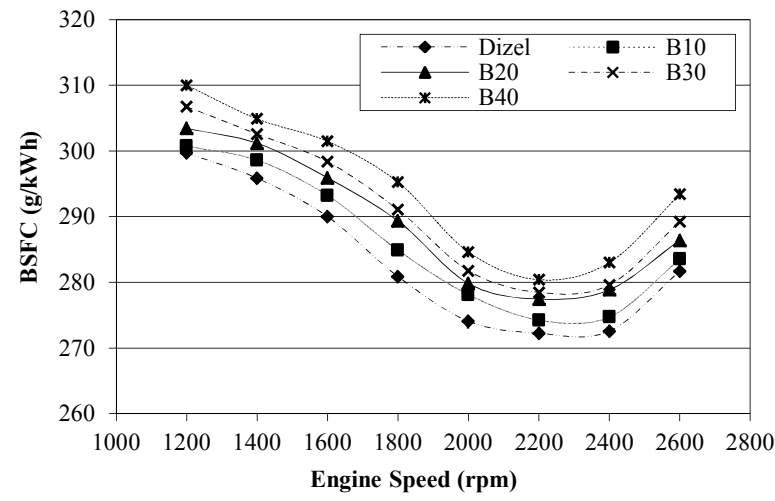

Figure 5. Break specific fuel consumption at full load condition

\subsection{Engine Emission Results}

$\mathrm{CO}$ is a product formed due to incomplete combustion of fuels. Fossil-based fuels generate easily CO because there is not any oxygen in their molecular structure (Resitoglu et al., 2015). As seen in Figure 6, lower CO emission values were obtained with all blends compared to diesel. The maximum decrease rate in $\mathrm{CO}$ emission was $55.02 \%$ with B40 in 1200rpm. The minimum CO emission value was measured as $314 \mathrm{ppm}$ at $2200 \mathrm{rpm}$ with B40. Averagely the decreases in $\mathrm{CO}$ emissions were obtained as $30.70 \%, 36.17 \%, 37.73 \%$ and $41.45 \%$ for $\mathrm{B} 10$, $\mathrm{B} 20, \mathrm{~B} 30$ and $\mathrm{B} 40$ respectively. The main reason of decrease in $\mathrm{CO}$ emission with blends is the oxygen content in the biodiesel, which increases air/fuel ratio especially at rich regions in terms of fuel and helps for the complete combustion (Qi et al., 2010). 


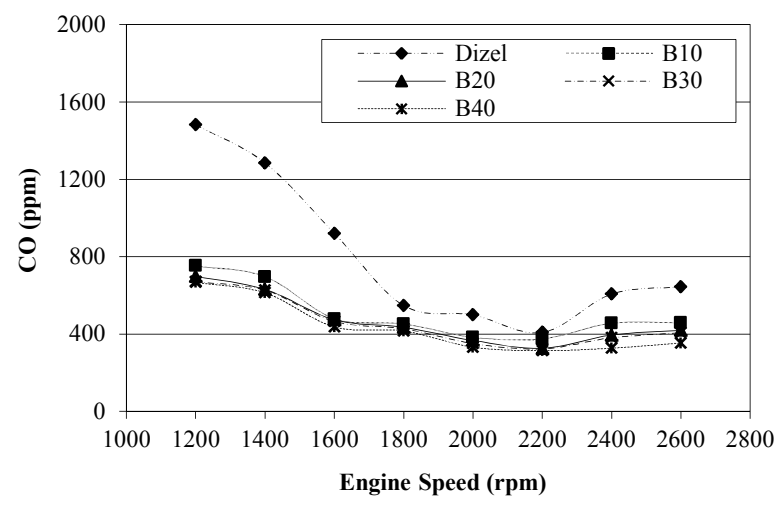

Figure 6. CO emissions at full load condition

The HC emission variations for different blends and diesel fuel are indicated in Figure 7. HC emission values decreased with all blends compared to diesel. The maximum $\mathrm{HC}$ emission values were measured at 1200rpm for all test fuels. Especially, $\mathrm{HC}$ emissions values were obtained higher in low engine speed due to low inlet airflow that affects turbulence and homogeneity of air-fuel mixture in the cylinder. The HC concentrations at $1800 \mathrm{rpm}$ (speed at maximum engine torque) was decreased by $30.06 \%, 40.13 \%, 45.03 \%$ and $55.11 \%$ with use of B10, $\mathrm{B} 20, \mathrm{~B} 30$ and B40 respectively comparing with diesel. These results show that $\mathrm{HC}$ emissions reduced significantly with use of biodiesel. The reduction of $\mathrm{HC}$ emissions could be explained with the complete combustion of the fuel droplets.

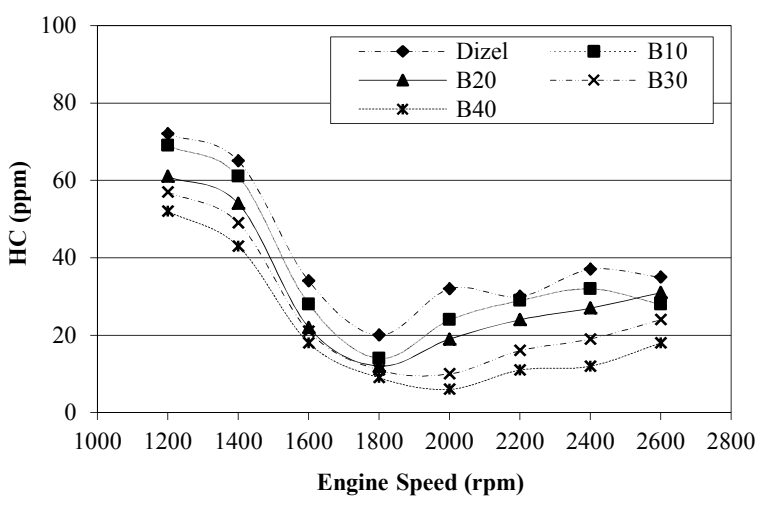

Figure 7. HC emissions at full load condition

$\mathrm{NO}_{\mathrm{x}}$ emission values of test fuels are given in Figure 8. As shown in figure, $\mathrm{NO}_{\mathrm{x}}$ concentration was increased in direct proportions with increases in percentage of biodiesel. $\mathrm{NO}_{\mathrm{x}}$ emissions between 1400 and 1800rpm engine speeds were obtained higher than those at other engine speeds for all test fuels. Especially, $\mathrm{NO}_{\mathrm{x}}$ emission values increased to the highest level near the engine speeds at which maximum torque was obtained. In the continuation of these speeds, $\mathrm{NO}_{\mathrm{x}}$ emission was decreased with increase in engine speed because of shorter residence time available for formation of $\mathrm{NO}_{\mathrm{x}}$. Use of biodiesel led to increase in $\mathrm{NO}_{\mathrm{x}}$ emissions averagely $8.72 \%$ for $\mathrm{B} 10$, $11.12 \%$ for $\mathrm{B} 20,12.55 \%$ for $\mathrm{B} 30,17.64 \%$ for $\mathrm{B} 40$. Other researchers obtained similar increases in $\mathrm{NO}_{\mathrm{x}}$ emissions with use of biodiesel (Lapuerta et al., 2008; Lin et al., 2009). It is estimated that the increase in $\mathrm{NO}_{\mathrm{x}}$ emissions depends on high temperatures of combustion meaning improvement of combustion with use of biodiesel. 


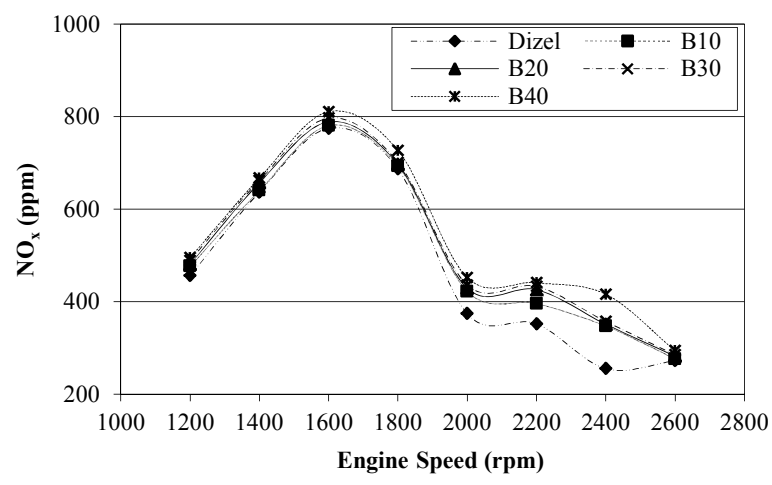

Figure 8. $\mathrm{NO}_{\mathrm{x}}$ emissions at full load condition

Figure 9 shows smoke opacity values of the test fuels at full load condition. The smoke is formed due to incomplete combustion and denoted by the ratio of light absorb coefficient (K) (Qi et al., 2010). Compared to diesel fuel, smoke opacity values of blends decreased at all engine speeds. The minimum smoke opacity value was measured as $0.25 \mathrm{~L} / \mathrm{m}$ at $2000 \mathrm{rpm}$ with B 40 . The smoke opacity values were higher at high and low engine speeds compared to medium engine speeds. Maximum reduction in smoke opacity was obtained as $40.48 \%$ with B40 at 2000rpm. Smoke opacity values decreased averagely $7.80 \%$ with B10, $10.77 \%$ with B20, $14.68 \%$ with B30 and $20.19 \%$ with B40.

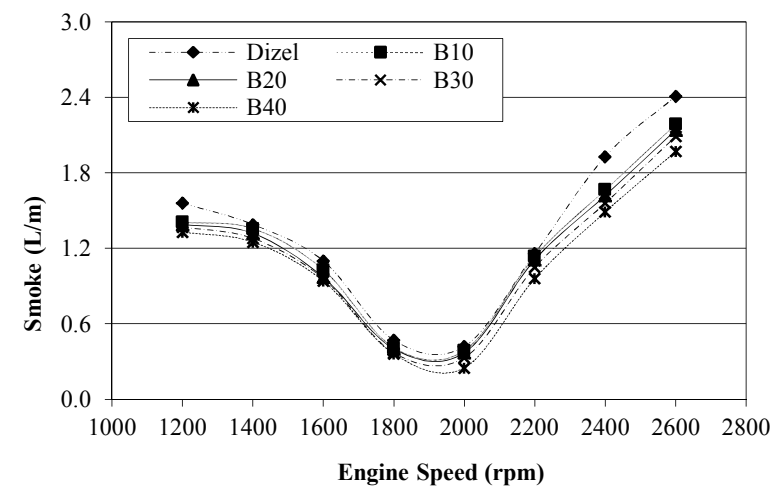

Figure 9. Smoke opacity values at full load condition

\section{Conclusion}

This paper focused on production biodiesel from waste oil and use as an alternative fuel in CI engines. Waste oil contained high rate of free fatty acid was obtained from a refectory's oil separator and esterified to get biodiesel. Brief engine tests were conducted using different combinations of biodiesel and diesel fuel. In conclusion, the engine torque and power decreased slightly while BSFC increased in direct proportions with increases in percentage of biodiesel. Maximum increase in BSFC was obtained as $4.86 \%$ with B40 at $1800 \mathrm{rpm}$.

The use of biodiesel derived from waste oil as a blend fuel in diesel engine improved the emission characteristics. Compared to diesel, significant reductions were detected in $\mathrm{CO}$ and $\mathrm{HC}$ emissions with blended fuels while $\mathrm{NO}_{\mathrm{x}}$ concentration increased slightly. Maximum decreases in $\mathrm{CO}$ and $\mathrm{HC}$ emissions were obtained with B40 respectively as $55.02 \%$ at $1200 \mathrm{rpm}$ and $81.25 \%$ at $2000 \mathrm{rpm}$. Use of biodiesel led to decrease up to $40.48 \%$ in smoke opacity. Finally, this study indicated that the biodiesel produced from waste oil could be used in diesel engine. The use of waste oil as an alternative fuel has a positive impact upon ecological and economic sense.

\section{References}

Ahmed, S., Hassan, M. H., Kalam, M. A., Rahman, S. M. A., Abedin, M. J., \& Shahir, A. (2014). An experimental investigation of biodiesel production, characterization, engine performance, emission and noise of Brassica juncea methyl ester and its blends. Journal of Cleaner Production, 79, 74-81. https://doi.org/10.1016/j.jclepro.2014.05.019 
Chuah, L. F., Yusup, S., Aziz, A. R. A., Bokhari, A., \& Abdullah, M. Z. (2016). Cleaner production of methyl ester using waste cooking oil derived from palm olein using a hydrodynamic cavitation reactor. Journal of Cleaner Production, 112, 4505-4514. https://doi.org/10.1016/j.jclepro.2015.06.112

Eguchi, S., Kagawa, S., \& Okamoto, S. (2015). Environmental and economic performance of a biodiesel plant using waste cooking oil. Journal of Cleaner Production, 101, 245-250. https://doi.org/10.1016/j.jclepro.2015.04.008

Gürü, M., Can, Ö., Koca, A., Çınar, C., \& Şahin, F. (2010). Biodiesel production from waste chicken fat based sources and evaluation with $\mathrm{Mg}$ based additive in a Diesel engine. Renewable Energy, 35, 637-643. https://doi.org/10.1016/j.renene.2009.08.011

Kalligeros, S., Zannikos, F., Stournas, S., Lois, E., Anastopoulos, G., Teas, C., \& Sakellaropoulos, F. (2003). An investigation of using biodiesel/marine diesel blends on the performance of a stationary diesel engine. Biomass and Bioenergy, 24, 141-149. https://doi.org/10.1016/S0961-9534(02)00092-2

Keskin, A., Gürü, M., Altıparmak, D., \& Aydın, K. (2008). Using of cotton oil soapstock biodiesel-diesel fuel blends as an alternative diesel fuel. Renewable Energy, 33, 553-57. https://doi.org/10.1016/j.renene.2007.03.025

Keskin, A., Ocakoglu, K., Resitoglu, I. A., Avsar, G., Emen, F. M., \& Buldum, B. (2015). Using Pd(II) and Ni(II) complexes with N,N-dimethyl-N0-2-chlorobenzoylthiourea ligand as fuel additives in diesel engine. Fuel, 162, 202-206. https://doi.org/10.1016/j.fuel.2015.09.023

Kochepka, D. M., Dill, L. P., Couto, G. H., Krieger, N., \& Ramos, L. P. (2015). Production of Fatty Acid Ethyl Esters from Waste Cooking Oil Using Novozym 435 in a Solvent-Free System. Energy Fuels, 29, 8074-8081. https://doi.org/10.1021/acs.energyfuels.5b02116

Lapuerta, M., Armas, O., \& Rodriguez-Fernandez, J. (2008). Effect of biodiesel fuels on diesel engine emissions. Progress in Energy and Combustion Science, 34, 198-223. https://doi.org/10.1016/j.pecs.2007.07.001

Lin, L., Ying, D., Chaitep, S., \& Vittayapadung, S. (2009). Biodiesel production from crude rice bran oil and properties as fuel. Applied Energy, 86, 681-688. https://doi.org/10.1016/j.apenergy.2008.06.002

Özsezen, A. N., Çanakçı, M., Türkcan, A., \& Sayın, C. (2009). Performance and combustion characteristics of a DI diesel engine fueled with waste palm oil and canola oil methyl esters. Fuel, 88, 629-636. https://doi.org/10.1016/j.fuel.2008.09.023

Qi, D. H., Chen, H., Geng, L. M., Bian, Y. Z., \& Ren, X. C. (2010). Performance and combustion characteristics of biodiesel-diesel-methanol blend fuelled engine. Applied Energy, 87, 1679-1686. https://doi.org/10.1016/j.apenergy.2009.10.016

Qi, J., Zhu, F., Wei, X., Zhao, L., Xiong, Y., Wu, X., \& Yan, F. (2016). Comparison of biodiesel production from sewage sludge obtained from the $\mathrm{A}^{2} / \mathrm{O}$ and $\mathrm{MBR}$ processes by in situ transesterification. Waste Management, 49, 212-220. https://doi.org/10.1016/j.wasman.2016.01.029

Resitoglu, I. A., Altınışık, K., \& Keskin, A. (2015). The pollutant emissions from diesel-engine vehicles and exhaust aftertreatment systems. Clean Techn Environ Policy, 17, 15-27. https://doi.org/10.1007/s10098-014-0793-9

Sanjid, A., Masjuki, H. H., Kalam, M. A., Rahman, S. M. A., Abedin, M. J., \& Palash, S. M. (2014). Production of palm and jatropha based biodiesel and investigation of palm-jatropha combined blend properties, performance, exhaust emission and noise in an unmodified diesel engine. Journal of Cleaner Production, 65, 295-303. https://doi.org/10.1016/j.jclepro.2013.09.026

Shadid, E. M., \& Jamal, Y. (2008). A review of biodiesel as vehicular fuel. Renewable and Sustainable Energy Reviews, 12, 2484-2494. https://doi.org/10.1016/j.rser.2007.06.001

\section{Copyrights}

Copyright for this article is retained by the author(s), with first publication rights granted to the journal.

This is an open-access article distributed under the terms and conditions of the Creative Commons Attribution license (http://creativecommons.org/licenses/by/4.0/). 